\title{
APOL1 Gene
}

National Cancer Institute

\section{Source}

National Cancer Institute. APOL1 Gene. NCI Thesaurus. Code C138151.

This gene is involved in the transport of cholesterol and other lipids. 